\title{
The Analysis of Coccyx (enobliaT) and the Effect on Physical Resurrection Theory
}

\author{
Mansoureh Saeidpoor Sarcheshmeh ${ }^{1}$, Farahnaz Razmi ${ }^{2}$, Mehri Valipour ${ }^{3}$ \\ ${ }^{1,2,3}$ Kerala University, Department of Linguistics, Kariavatiom P.O, Thiruvananthapuram Kerala, India
}

\begin{abstract}
God created human based on the wise and science that surprised the scientists and physicians and made them give different ideas about body and soul. Although these ideas seem different but encourages human to think deeply but proves the glory of human creation. The aim of this paper is to analyze the coccyx by physicians, especially philosophers such as Mulla Sadra continuing Ebne Arabi and Feyz kashani. The paper is written and submitted based on the scientific and philosophical principles.
\end{abstract}

Keywords: coccyx, body, soul, self, intake, life, world, death, theory, God

\section{Introduction}

It is about human nature remains after death it is as small as a bean in human body. And god collects it again in resurrection day. Actually the subject has nothing to do with nature, but it is said for the bone called as coccyx. In a strange narrating from the messenger said: whole body of the person will be decomposed except coccyx and the person will be made again of it (ahih Moslem book 7page 21) But to what fact the narrating is pointing in human body?

The research is a reply to this secret, since my ability cooperates.

What is the reality of (O.Z) coccyx There are different ideas about the remaining nature called coccyx of human after death some say it is the original organ of the body.
The picture above shows the coccyx:

Views of philosophers about the coccyx:

Philosophers, speakers, and wise men believe: when the self gets separated from the body, a weak item remains with the self, called as coccyx in narrations.

But philosophers have different views that what is coccyx?

Ebn e Arabi and Sadro 1 moteallehin have different views in this case.

Ebn e Arabi says: coccyx is that stable part of human body which remains with human self forever.

Although Mulla Sadra point to the messenger narration in his prof, that what remains from human in this world is the beginning point of him in the other world as his body,

He says: after the separation of the body and soul a weak item remains from the body called in narrations as coccyx that means the rest of tail, in which scientists are not agreed about the meaning.

And some say: it is genes so different from the first narrating.

Some say: it is the first substance.

Some say: the remaining feature is intake (self)

Others say: it is the person element.

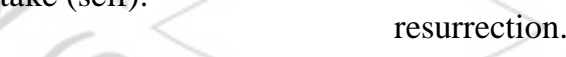

But Mulla Sadra believes coccyx means: imagination power, because it is the last phenomenon got from other powers, and it is the first power with that human come across in resurrection.

Mulla Sadra writes in Arshiye: this power is the keeper of outside forms that after body destruction can be the source of them again, so there is a limbo between this word and the other world, so imagination power is the roof of this world and the carpet of the other world, means it is the rest of human imagination power which separates self from body and its last source is the first and the last of another source. (Arshiyye, 1360. P16)

From Mulla Sadrsa point of view, human imagination power is his lowest solitary rank, so this power is the link single self and materialistic body.

At the time of death, body gets disjointed, and the only thing remained from human is this power which gets created totally the same again in limbo after separation from the materialistic body, the recreated body by imagination power is called limbo body of human.

So according to Sadra idea, the messenger named imagination power, (o.z.) / coccyx, because the coccyx (the last bones of spine) is the link between the upper half and
1.1. It means the bone of spine which never destroys. Great philosophers call it the main part of the body. And God make our body again out of this part in resurrection. 


\section{International Journal of Science and Research (IJSR) \\ ISSN (Online): 2319-7064}

Index Copernicus Value (2013): 6.14 | Impact Factor (2015): 6.391

the lower half, means it is a link between the noble half and the mean half.

Imagination power is the link between human single prestige (soul or self) and materialistic prestige that is the body.

\section{Perhaps it is the most convincing explanation from the messenger words.}

Physical resurrection in high wisdom:1.2.

Muslim scientists had special attention to resurrection and discussed a lot about it, some of Muslim philosophers proved the spiritual resurrection by philosophical reasons but physical resurrection by religion.

Among these philosophers, Mulla Sadraha having a special and particular thought at that time submitted a different theory about physical resurrection. He writes in the book, first day and last day, all Muslims believe in the last day, but there are different ideas about it. (al hekmato 1 Motealiyye fi afsar el aghliyye, alarbaee, 1379, B. 9- P. 384)

Mulla Sadrs having new and original ideas in divine philosophy succeeded to affect the next generation in many other subjects.

He believes that after human birth to this world he has another birth in resurrection. Although the details are of this resurrection not exactly clear (Shavahed al robubiyye, p404).

Mulla Sadra according to his philosophical principles believed that resurrection should happen by different body. Materialistic (substance) body replaces by spiritual body (soul) in resurrection which has completely different characteristic from the body on earth.

And at the he came to the result that physical and spiritual resurrection will happen together.(Shavahed al Robubiyye, 1375 , p. 335).

The recollection of spread dead body organs or reconstruction of them: What we get from previous discussion is that the resurrected person physically and spiritually is exactly the person living in this world, because realizing it depends on the duration of self with a passive and general material which happens for a special and active material., it is Mulla Sadra's belief about resurrection.

Anyone who denies it means denying an important principle of faith, and he will be wisely and religiously unbeliever and heterodox and should deny many instructions of the book and sunna. (alshavahed ol Robubiyye, 1375, p.381-385)

But Ebn e Arabi believes the human will be recreated in resurrection by the same face he had in this world.(fotuhat $\mathrm{e}$ makiyye, ebn e arabi, B.2, P.304-308)

But Mulla Sadra disagrees because he believes this world and the other world are two different worlds, and the base on which human will be created on resurrection day cannot be the same face in the world.
Mulla Sadra reminds of the other world human corps to understand better and clearer in some items:

1.3. Hereafter human body does not accept death, illness and oldness(1361, Arshiyye, p.250)

Hereafter body is one of the necessary selves to be like a shadow for soul. (Alhekmah Motealiyye,fi afsar al aghliyye4, B.9. 1379, p.32)

Souls forming and equality with self, hereafter body is the meaning of soul formation which happens in the other world not here. (Hman, B.9, 1379, p.184)

Hereafter body of any person is sensible by apparent senses there./(haman, 1379, b.9, p.254)

Hereafter body is completely matched with his characteristics (this world and the other world,1380, p.460)

So Mulla SAdara narrating some characters of hereafter body concluded that what presents in resurrection is the world body acoording to the appearance and intake, but with an unclear material. (Alhekma Motealiyye.....1379, b.9, p.32)

So the hereafter bodies are exactly the earth bodies not the copy.

2.1. Now the question is, when the sample model exists?

Does it happen after the separation of the soul from the body?

Or it was with the body and soul in this world?

The answer is, at the time of death and transferring from earth, materialistic body remains in graves and all organs get separated and become a part of earth, no more body is there to be matched as a human, because everything is destroyed but the model of alive body on earth is still available and continues living in the other world.

Mulla m.f. Kashani believes the model was available on earth and the corps is the case in which soul was available also, so this model is in materialistic body.

The model is available on earth now with the corps, alive with its live and all part of human will be the same for future.

It is a natural rule that second step is out of the previous one so without the first phase, the next 0ne will not happen. He believes the existence of the model is from physic, so this body is like a cover for it (knowing Islamic science shahid, M, Motahhari/114,p.1) (Mulla f. Kashani, in the book hidden words from philosophers science is:

The model is the same as physical body surrounded by soul and used by it. because the model on earth is with the materialistic body which have the same lives, life is essential for it and created by earth corps and it is like a cove for the 


\section{International Journal of Science and Research (IJSR) \\ ISSN (Online): 2319-7064}

Index Copernicus Value (2013): 6.14 | Impact Factor (2015): 6.391

resurrected model. /Mohiyyedin ebn e Arabi, a great Character in Islamic knowledge, Mohsen Jahangiri/ 419

Yes, from a dead body just remains some meat and bones except his inside/ intake/ soul/ self which created by God and never spoiled or destroyed till resurrection with which the first body comes out.

So in some narrations human self means the first material for living after death in resurrection, has been called o.z or coccyx, as an innocent character said: whole body of Adam child will be spoiled except coccyx means his self, life material in resurrection.(Beharo 1 Anvar, B.43/7).

So the body model is a kind of corps through which the soul penetrate, on earth both of them means the body and soul are together now.

F.Kashani believes when we talk about the model, it does not mean that appear after death and his reason is sleeping. He says: human soul gets separated from body in this world but body is its mold which continues living after death in the form of body model but more soft and delicate. He believes as human self has a mold in sleeping the same is available for corps and soul which will be alive with them.

F.Kashani gives a better example about this subject, suppose a walnut it has two shells one soft which is inside the hard one.

Actually the mold we have in this world is the hard shell of our body and it is normal to have a soft shell like walnut inside this body and we take this soft and delicate shell with us to the other world.

The life of this body model is from material making our physic, the same items made the body model belonging to the other world.

2.2.To understand the subject better, we should say it is a natural rule in different stages of creation, the next step happens because of the last step. When no previous step, there will be no next one, our body is also like this, created by sperm and it is from earth and when there is no previous earth step, there will be no body, soul or body model. So from F.Kashani point of view this body is like layer or shell for it.

But Mulla Sadra in another explanation, as "eastern doctrine" says something else about the quality of human body resurrection, inside any human plus skin and appearance, an animal with human character, there are complete senses and powers that the animal is inside every human being in this world and will not die with death of the physical body.

Because its life is not like earth body but it has a spiritual body like soul, it is a semi-animal between sensible and wise animal, and will be resurrected like the actions and thoughts of the human. So what resurrects in the other world is the same body inside the self, to answer God for the right and wrong he did. (Alshavahed alrobubiyye,1346,p.288)
In body model resurrection Mulla Sadra has a new idea, according to his point of view, self in completion reaches a stage that becomes needless of earth body and after body destruction, it remains and death never hurts its qualities (Arshiyye, Sadr ol moteallehin,1361,p.248) and for the completion it is impossible for it to get back to the earth body, so makes a model shape for itself following received thoughts and goodness.

Mulla Sadra knows the source of the model body from the earth body and says: resurrected body will be present after death from the same body on earth buried in the grave.

Mulla Sadra knows the materials of the body made of self and intake in this world, and says: The items of the resurrected persons consisting of intake thoughts and desires because the other world is not the same as this world.

\section{Conclusion}

The result of the three philosophers' ideas is the agreement of Mulla Sadra and Feyz Kashani in the subject "Ojbo 1 Zanab" or coccyxand finally the analysis of physical resurrection but Ebn e Arabi ideas according to coccyx theory is different from the two other philosophers.

Since Ebn e Arabi believes coccyx is the same as human body permanently with the self and come to the result that the shape human will be present in resurrection is the same natural shape in this world.

But Mulla Sadra is against because he believes this world and the other world are different, and the form with it human resurrect cannot be the same form on earth.

Mulla Sadra proving his theory about resurrection of model bodies, points to six to twelve principles in his different works and concluded that both body and self or soul will get open in all cases, because body character will change according to the size, position and other factors, so the survival of the intake causes no harm to the human body.

Spiritual body which is the completion rank for physical body and it is one item of it, depends on spiritual apparent senses. This simple and shiny body has no death but is matched with good selves and actions. Mulla Sadra explains the body resurrection in two ways. He says in some works about body resurrection by itself but with an unclear substance and in the other works points to model body resurrection from imagination power.

He knows all doubts, questions and errors about body resurrection from unawareness and lack of knowledge and believes anyone who thinks deeply and frankly with a clean self, all doubts will be removed.

Feyz Kashani is agreed with Mulla Sadra he also believes the body model having souls after death is from earth body and sleeping is its reason and also the body model in this world and before death is made of material on earth not after death. 


\section{References}

[1] God help

[2] Arshiyye writing, corrected and translated by G.H. Ahani,1362, publisher, Mula

[3] Alhekma Motealiyye fi Afsar al Aghliyye4,1379, B.1,2,5,9.Ghom, pub.Mostafavi

[4] Alshavahed al Robubiyye, Sadr ol Moteallehin m.a, translated by J.Mosleh,Tehran,soroush, 1357

[5] Fotuhat Makiyye, Ebn e Arabi,beyrout,pub. Sader

[6] Asrar ol Ayat, Sadr ol Moteallehin Shirazi, 1385, searched by s.m mousavi,Tehran,hekmat,B.1

[7] Explanation and philosophical votes of Mulla Sadra, sj.Ashtiyani/214,publisher Muslim women organization 1360

[8] Alshaved al Robubiyye, corrected by j.Ashtiyani, mashhad,1346,pub. Mashhad university

[9] he first day and the last day, corrected by sj,Ashtiyani,1380,pub. Islamic advertising office.

[10] Behar ol Anvar B.43/7,B.358/60, Islamic house book, tehran 1360 . 